\title{
Częstość występowania wybranych cech niemetrycznych czaszki w zależności od cribra orbitalia i wyposażenia grobów
}

\author{
Pawel Bergman
}

\begin{abstract}
OCCURRENCE FREQUENCY OF SELECTED NON-METRICAL FEATURES OF CRANIUM DEPENDING ON CRIBRA ORBITALIA AND THE EQUIPMENT OF GRAVES. The occurrence of some non-metrical features can be conditioned by the paragenetic factors. This fact must be taken into consideration in studies on the so called biological distances between populations.
\end{abstract}

Od czasu ukazania się w 1967 roku publikacji autorów angielskich [BERRY, BERRY 1967] datuje się ogromny wzrost zainteresowania cechami niemetrycznymi ("epigenetycznymi") czaszki ludzkiej oraz wzrost ich znaczenia w różnych dziedzinach biologii populacji szkieletowych. Pomimo wielkiego entuzjazmu i ogromnej liczby publikacji, nie rozwiązano dotąd wielu problemów o znaczeniu podstawowym. Dotyczą one na przyklad zależności tych cech od wieku i plci, asymetrii, korelacji między nimi, podatności na czynniki srodowiskowe, a nawet nomenklatury i definicji (CZARNETZKI [1971, 1972]; CORRUCCINI [1974]; PERIZONIUS [1979]; RÖSING [1982]; HAUSER, BERGMAN [1984]; BERGMAN, HAUSER [1985] i inni).

Przyczyną entuzjastycznego nastawie-

Zakład Antropologii PAN

ul. Kuźnicza 35, 50-951 Wroclaw nia do cech "epigenetycznych" bylo nieuzasadnione przeświadczenie o wysokim stopniu ich determinacji genetycznej, a nawet o monogenicznym sposobie dziedziczenia. Źródlem tego przekonania byla przede wszystkim wspomniana publikacja (BERRY, BERRY [1967]), jak również bezkrytyczne przenoszenie na czlowieka wyników eksperymentalnych badań genetycznych, prowadzonych glównie na myszach. W rzeczywistości miarodajne informacje o stopniu determinacji genetycznej dotyczą tylko 5 - 6 cech; pochodzą one $z$ badań medycznych na czlowieku żywym i częściowo $\mathrm{z}$ badań genetycznych prowadzonych na malpach [RÖSING 1982]. Brak danych o stopniu determinacji genetycznej i ekosensytywności przytlaczającej większości cech niemetrycznych niewątpliwie utrudnia porównania międzypopulacyjne metoda odleglości wielocechowych, badanie procesów mogących zmieniać strukturę gene- 
tyczną populacji $\mathrm{i}$ inne badania $\mathrm{w}$ dziedzinie paleogenetyki populacyjnej.

Zagadnienie dziedziczności cech niemetrycznych, a zwlaszcza modeli ich dziedziczenia jest trudne do rozwiązania. Sądzę, że zagadnienie to można by odwrócić badając ekosensytywność tych cech, wplyw dających się wyodrębnić czynników środowiskowych na formy przejawiania się, stopień wyksztalcenia, częstości ich występowania itp.

Zgodnie $\mathrm{z}$ takim ujęciem zagadnienia można wstępnie sformulować kilka szczególowych pytań: 1) Czy pewien czynnik chorobowy, o którego istnieniu wnioskuje się na podstawie obecności tzw. cribra orbitalia, wplywa na częstości występowania niektórych cech niemetrycznych? 2) Czy częstości występowania niektórych cech niemetrycznych zależą od poziomu warunków bytowych (określonych obecnością lub brakiem wyposażenia grobów)? Odpowiedź na drugie pytanie wymaga uprzedniego stwierdzenia, czy obecność wyposażenia grobów może świadczyć o lepszych warunkach bytowych, w których żyl dany osobnik lub grupa osobników.

\section{Material}

Analiza oparta jest na serii 436 czaszek, wylącznie doroslych osobników. Seria ta pochodzi z cmentarzyska rzędowego $w$ Miliczu (Dolny Śląsk). Określenia wieku i pici czaszek udostępnione mi zostaly przez doc. dra B. Miszkiewicza, za co skladam mu podziękowanie. Material podzielilem na dwie grupy wiekowe (tab. 1): mlodszą (adultus) i starszą (maturus). Dokladniejszy podzial na klasy wieku dla potrzeb tej pracy nie jest konieczny.
Tabela 1. Podzial zbadanych czaszek z Milicza wedlug plci i wieku (osobnicy dorośli)

\begin{tabular}{l|r|r|r}
\hline & Adultus & Maturus & Razem \\
\hline Czaszki męskie & 90 & 152 & 242 \\
Czaszki żeńskie & 108 & 86 & 194 \\
Razem & 198 & 238 & 436 \\
\hline
\end{tabular}

Wedlug Miszkiewicza (informacja ustna) cmentarzysko milickie datowane jest na początek XII - koniec XIII wieku. Natomiast WACHOWSKI [1969, 1970, 1971, 1975] na podstawie szczególowej analizy materialów archeologicznych datuje to cmentarzysko na drugą polowę XII do pierwszej polowy XIV wieku.

Spośród 55 określonych na każdej czaszce cech niemetrycznych, do niniejszej analizy wybralem 9 cech, które podzielilem na dwie grupy.

Grupa I: 1. Sutura frontalis (szew czolowy); 2. Torus palatinus (wal podniebienny); 3. Foramen supraorbitale (otwór nadoczodolowy); 4. Tuberculum praecondylare (guzek przedklykciowy kości potylicznej); 5.Canalis hypoglossi bipartitus (kanal nerwu podjęzykowego dwudzielny).

Sa to cechy, w odniesieniu do których istnieją w literaturze dane świadczące o dość wysokim stopniu ich determinacji genetycznej. Dane te pochodzą z badań radiologicznych (cechy 1 i 3) i stomatologicznych (cecha 2) na czlowieku żywym oraz częściowo $\mathrm{z}$ badań na malpach (cechy 4 i 5) [RÖsing 1982].

Grupa II: 6. Foramen acusticum Huschkei (lub foramen tympanicum; otwór "sluchowy" Huschkego); 7. Spina trochlearis (kolec bloczkowy, w oczodole); $8 . \mathrm{M}_{3}$ maxillae (trzeci ząb trzonowy szczęki); 9. Ossicula suturae lambdoideae (kostki wstawne szwu węglowego). 
Wlaściwości anatomiczne tych cech oraz fakt, iż ksztal tują się one lub kończą ksztaltowanie się w różnych okresach po urodzeniu pozwalają przypuszczać, że mogąulegać wplywom różnych czynników środowiska zewnętrznego (odżywianie, choroby itp.). Dotyczy to w szczególności kostek wstawnych szwu węglowego [HESS 1946, BENNETT 1965, FINKEL 1971] oraz w dużym stopniu cech I grupy.

Nazwy lacińskie cech (z wyjątkiem 7 i 8) podane są wedlug projektu nomenklatury cech niemetrycznych, który opublikowali CORRENTI, PASSARELlo i VÉCCHI [1979].

Cribra orbitalia określilem wedlug skali HENGENA [1971]. Jednakże dla potrzeb niniejszej pracy wystarczający jest podzial alternatywny "obecność - brak". Osobnicy mający cribra orbitalia podzieleni zostali na dwie podgrupy: $z$ obustronną i tylko $z$ jednostronną obecnością tej cechy.

\section{Omówienie wyników i dyskusja}

\section{Cechy niemetryczne a cribra orbitalia}

Cribra orbitalia zostaly opisane po raz pierwszy przez WELCKERA [1888] jako cecha rasowo-diagnostyczna. Bardziej trafną nazwę hyperostosis spongiosa tecti orbitae zaproponowal HENGEN [1971]. Pojawiają się one na górnej ścianie oczodolu jako zmiana patologiczna, w wyniku której cienka warstwa zbita tej ściany przeksztalca się W przerośniętą substancję gąbczastą ("zgąbczenie kości") i przyjmuje wygląd sita lub rzeszota (hyperplazja i hypertrofia diploë stropu oczodolu). Zmiany te wywolane są glównie nadaktywnością czerwonego szpiku kostnego. Zdaniem wielu autorów przyczyną są różne postacie anemii, przede wszystkim $z$ powodu niedoboru żelaza i niektórych innych mikroelementów w pożywieniu (magnez, chlor) oraz być może kwasu foliowego, zakażenia pasożytami (przede wszystkim robaczyce), niekiedy malaria, jak również niektóre anemie wrodzone, np. thalassemia [ANGEL 1967, HENGEN 1971, CARLSON i inni 1974, STEINBOCK 1976, BROTHWELL 1981, FORNACIARI i inni 1981, JANSSENS 1981, GLADYKOWSKA-RZECZYCKA 1982, SANDFORD i inni 1983, GUIDOTTI 1984].

$\mathrm{Z}$ wymienionych powodów cribra orbitalia sa dobrym wskaźnikiem warunków bytowych w sensie stanu zdrowotnego populacji, poziomu warunków sanitarno-higienicznych, żywieniowych itp. BROTHWELL [1981] określa je mianem environmental indicator. FORNACIARI i inni [1981] uznają je za dobry test standardu żywieniowego populacji, a nawet zróżnicowania spolecznego. Sądzę, że można użyć określenia "wskaźnik zabiedzenia"; w takim sensie cecha ta jest użyta w dalszej analizie. Informując bowiem o przebytym schorzeniu, informuje zarazem o niekorzystnych sytuacjach środowiskowych, sprzyjających temu schorzeniu.

Cribra orbitalia mogą pojawiać się już wkrótce po urodzeniu, a więc w okresie, gdy ksztaltują się jeszcze także liczne cechy niemetryczne czaszki. Wykazano także, że przyczyny wywolujące cribra orbitalia mają również duży wplyw na rozwój i zmiany kości czaszki (REIMANN,GÖKMEN [1966]; REIMANN, KURAN [1973] i inni), w tym także na okolice występowania wielu cech niemetrycznych.

Konieczne jest zatem zbadanie, czy wymieniony czynnik chorobowy, tj. anemia wplywa na częstości występowania niektórych cech niemetrycznych. Można bowiem przyjąć, że czynnik ten może niektóre procesy osyfikacyjne czy to hamować, czy 
to pobudzać, zmieniając tym samym formy wyksztalcenia niektórych cech, a więc i częstości ich występowania. Przyjąlem, że osobnicy bez cribra orbitalia bytowali w "średnio lepszych" warunkach pod względem wyżywienia, poziomu higieny, cechowali się lepszym stanem zdrowia itd. Osobnicy zaś posiadający tę cechę bytowali w "średnio gorszych" warunkach pod wymienionymi względami.

Tabela 2. Częstośc występowania cribra orbitalia u osobników dorosłych z Milicza (\% do $N_{\text {stron) }}$

\begin{tabular}{c|c|c|c}
\hline & Strona prawa & Strona lewa & Razem \\
\hline $\begin{array}{c}\text { Czaszki } \\
\text { męskie }\end{array}$ & $\begin{array}{c}26,2 \\
(61 / 233)\end{array}$ & $\begin{array}{c}34,5 \\
(79 / 229)\end{array}$ & $\begin{array}{c}30,3 \\
(140 / 462)\end{array}$ \\
Czaszki & $\begin{array}{c}26,2 \\
(48 / 183)\end{array}$ & $\begin{array}{c}33,0 \\
(63 / 191)\end{array}$ & $\begin{array}{c}29,7 \\
(111 / 374)\end{array}$ \\
\hline Rańskie & $26,2 *$ & $33,8^{*}$ & $\begin{array}{c}30,0 \\
(109 / 416)\end{array}$ \\
\hline
\end{tabular}

- $p<0,02$

W serii czaszek z Milicza (tab. 2) cribra orbitalia występują z częstością ok. $30 \%$ (w stosunku do liczby stron). W stosunku do liczebności osobników odsetek ten wynosi ok. $37 \%$. Liczby te nie odbiegają od danych dla innych serii europejskich i pozaeuropejskich, choć są znacznie wyższe niż średnie [HENGEN 1971; SANDISON 1976; STLOUKAL, VYHNÁNEK 1976; GUIDOTTI 1984]. Populację z Milicza należaloby zatem zaliczyć do zabiedzonych. Różnice plciowe nie zaznaczyly się. Ujawnila się natomiast znacznie wyższa częstość występowania cribra orbitalia po stronie lewej (tab.2). Zjawisko to obserwowali także inni autorzy (np. HENGEN [1971]). Częstości występowania dziewięciu cech niemetrycznych w zależności od obecności i braku cribra orbitalia przedstawione są w tab. 3 i 4.

U osobników mających cribra orbitalia (zwlaszcza obustronnie), w porównaniu z osobnikami bez tej wlaściwości, obserwuje się dużo wyższe częstości występowania jednych cech (tuberculum praecondylare u mężczyzn, foramen supraorbitale u kobiet), jak i dużo niższe częstości innych cech (canalis hypoglossi bipartitus u mężczyzn, ossicula suturae lambdoideae $i$ sutura frontalis u kobiet). Warto tu przypomnieć znany fakt, że czaszki sztucznie zdeformowane charakteryzują się dużą częstością występowania szwu czolowego; jest to przyklad wplywu czynnika zewnętrznego na częstość występowania cechy niemetrycznej.

Interesujące dane dotyczące tuberculum praecondylare podaje RösING [1982]. W jednym $\mathrm{z}$ badanych przez niego staroegipskich grobowców rodzinnych, liczących blisko 40 osobników, tuberculum praecondylare występuje w $47 \%$, podczas gdy w calym materiale w $13 \%$.

Rodzinne występowanie tej cechy mogloby świadczyć o znacznej kontroli genetycznej. Jednocześnie $\mathrm{z}$ tab. 3 wynika, że wzrostowi częstości występowania tej cech może sprzyjać czynnik chorobowy (przynajmniej u mężczyzn).

Charakterystyczna jest wysoka częstość występowania niektórych cech u osobników z jednostronną obecnością cribra orbitalia (torus palatinus u kobiet, trzeci ząb trzonowy szczęki u mężczyzn i kobiet). Wynik ten sugeruje istnienie dwóch form schorzenia, być może "lżejszej" (cribra orbitalia jednostronne) i "cięższej" (obustronne). Nasuwa się tu skojarzenie ze znaną w farmakologii i fizjologii regulą 
Tabela 3. Cechy grupy I a cribra orbisalia (\% do $N$ atron)

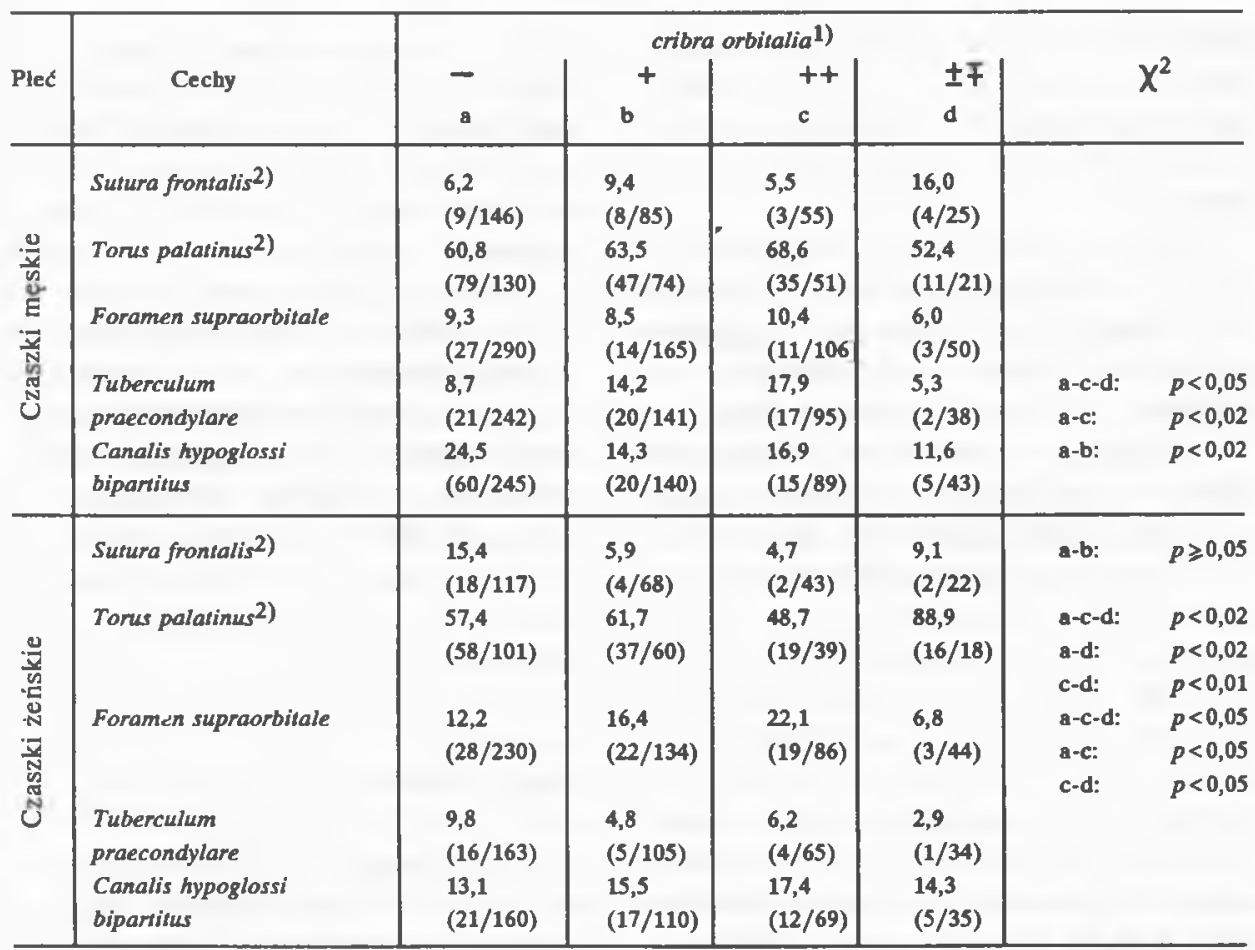

Objasnienia: 1) - obustronny brak, + jedno- lub obustronna obecnośc, ++ obustronna obecnośc, $\pm \mp$ jednostronna obecnosc; 2) \% do $N$ osobników

Tabela 4. Cechy grupy II a cribra orbiralia (\% do $N$ stron)

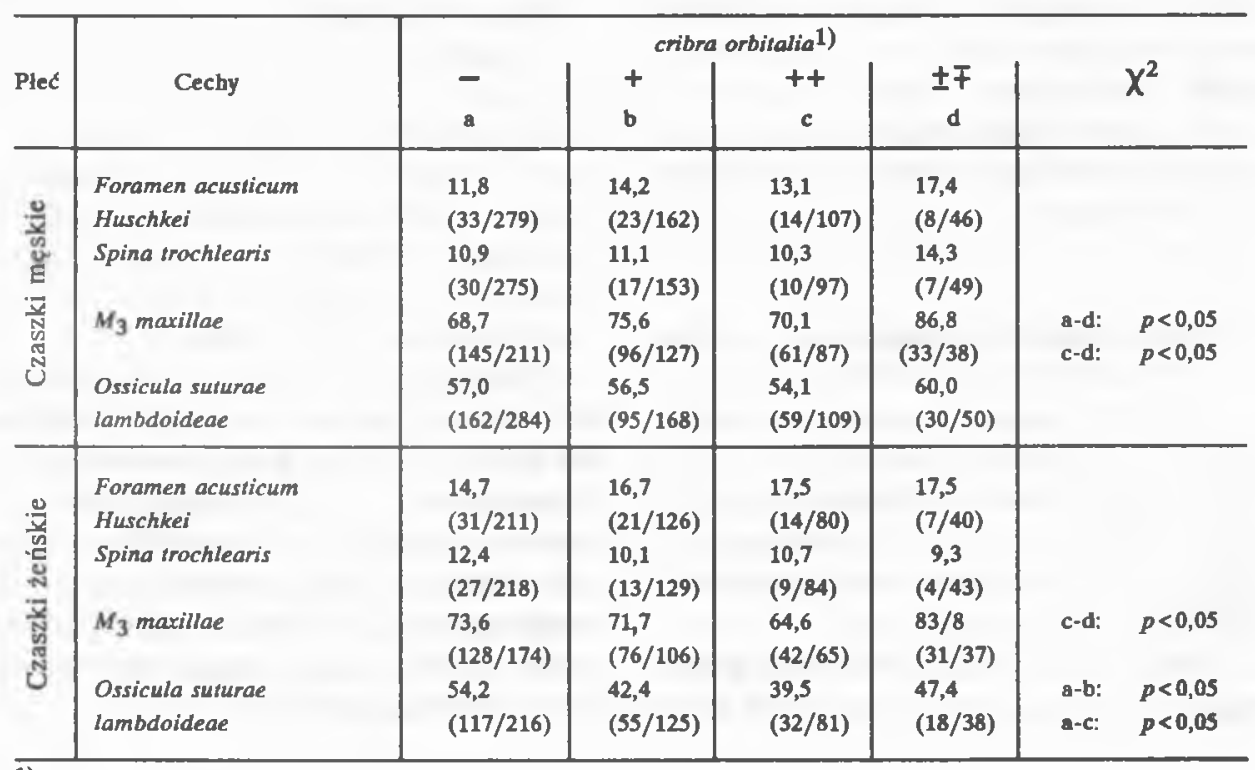

1) Objasnienia w tablicy 3. 
Arndta i Schultzego, zgodnie z którą slabe bodźce pobudzają różne procesy i funkcje organizmu, średnie - nasilają, silne - hamują, zaś bardzo silne - paraliżują [NIKITJUK 1975].

Ogólnie rzecz biorąc zaobserwowane różnice dotyczą 5 cech u kobiet i tylko 3 cech u mężczyzn. Jedynie pod względem dwóch cech różnice nie wystapily (foramen acusticum Huschkei i spina trochlearis).

Uzyskane wyniki, które należy, oczywiście, traktować jako wstępne, wskazują na to, że czynnik chorobowy, mający związek z poziomem warunków bytowych, stanem odżywienia itp. danej populacji, może zmieniać częstości występowania niektórych cech niemetrycznych, w tym także tych, które uważa się za silnie genetycznie uwarunkowane. Zmiany te są efektem pobudzania lub hamowania przez czynnik chorobowy procesów kostnienia drobnych w zasadzie anatomicznych elementów budowy czaszki. Należy zatem liczyć się z tym, że wielocechowe odleglości między populacjami mogą wskazywać nie tylko na różnice etniczne lub genetyczne między nimi, lecz częściowo także na różnice uwarunkowane czynnikami środowiskowymi. Ewentualne procesy selekcyjne, które moglyby mieć związek z zaobserwowanymi różnicami, będą przedmiotem odrębnej analizy.

\section{Cribra obitalia a wyposażenie grobów}

Jak wspomniano, odpowiedź na drugie pytanie sformulowane we wstępie, winna być poprzedzona stwierdzeniem, czy obecność wyposażenia grobów może świadczyé o lepszych warunkach bytowych, w których żyla dana grupa osobników.

Obecnośc lub brak inwentarza grobowego czy zmniejszanie się $w$ czasie liczby grobów z wyposażeniem, na przyklad na cmentarzyskach średniowiecznych, może mieć związek $\mathrm{z}$ wydarzeniami historycznymi, a nie z poziomem warunków bytowych, czy ewentualnie nawet ze zróżnicowaniem spolecznym. $\mathrm{Na}$ przyklad WACHOWSKI [1975] wyraża przypuszczenie, że charakter i różnice w wyposażeniu zmarlych nie byly w sposób bezpośredni uwarunkowane różnicami majątkowymi, spolecznymi i politycznymi, ani ogólnym poziomem gospodarki, ale przede wszystkim wierzeniami i zwyczajami pogrzebowymi. STLOUKAL [1970] jest zdania, że po wprowadzeniu chrześcijaństwa zacząl rozpowszechniać się zwyczaj chowania zmarlych bez dodawania jakichkolwiek przedmiotów do grobu; jest jednak malo prawdopodobne, że zwyczaj ten zaczął natychmiast powszechnie obowiązywać. Obecność inwentarza grobowego należaloby $w$ takim razie traktować jako relikt obyczaju pogańskiego. $\mathrm{Z}$ drugiej strony należy liczyć się także z przepisami kościelnymi, dotyczącymi mienia zmarlego. Należy również podkreślić, że miejscowość Milicz od ok. polowy XII w. (1136 r.) stala się wlasnością biskupstwa wroclawskiego, czy nawet osobiście biskupa. Można by zatem zalożyć, że nalożone od tego momentu przez wladze kościelne opodatkowanie moglo spowodować postępujące ubożenie tej ludności; niestety podzial badanego cmentarzyska na warstwy chronologiczne nie jest możliwy.

Okazalo się jednak, że w serii z Milicza bylo ok, $48 \%$ grobów żeńskich i zaledwie ok. 14\% grobów męskich $\mathrm{z}$ wyposażeniem. Proporcje te (nieco tylko inne dla cmentarzyska milickiego jako calości) są typowe dla okresu, z którego pochodzi ta seria, a przynajmniej dla Śląska, gdzie ponadto groby są $w$ ogóle ubogo wyposażone [WACHOWSKI 1975]. 
W związku z powyższymi proporcjami, dalsza analiza dotyczyć będzie tylko czaszek żeńskich, podzielonych na dwie grupy (tab. 5): bez wyposażenia (grupa BW) i z wyposażeniem (grupa W; co najmniej jeden przedmiot). Informacje o wyposażeniu grobów pochodzą z publikacji WACHOWSKIEGO $[1969,1970,1971]$. Przyjąlem zalożenie, że inwentarz grobowy świadczy o poziomie zamożności rodzin, z których pochodzą zmarli, a więc że osobnicy z grupy BW żyli w "średnio gorszych", zaś osobnicy $z$ grupy $W$ w "średnio lepszych" warunkach bytowych. W związku z tym można spodziewać się, że w grupie osobników BW wystąpi wyższy odsetek cribra orbitalia, niż w grupie W.

Tabela 5. Częstośc występowania cribra orbitalia w zależnosci od wyposażenia grobów ( $\%$ do $N$ stron) czaszki żeńskie

\begin{tabular}{l|l|l}
\hline Grupa wieku & BW & W \\
\hline \multirow{2}{*}{ Adultus + Maturus } & $33,8^{1)}$ & $25,0^{1)}$ \\
& $(67 / 198)$ & $(44 / 176)$ \\
Adultus & $40,8^{2), 3)}$ & $\left.23,6^{2}\right)$ \\
& $(42 / 103)$ & $(25 / 106)$ \\
Maturus & $\left.26,3^{3}\right)$ & 27,1 \\
& $(26 / 95)$ & $(19 / 70)$ \\
\hline
\end{tabular}

$$
\begin{aligned}
& \text { Objaśnienia: } \\
& \text { BW - brak wyposażenia grobów, } \\
& \text { W = obecnodé wyposazenia grobów } \\
& \text { 1) } 0,07>p>0,05 ;{ }^{2)} p<0,01 ;{ }^{3)} p<0,05 \text {. }
\end{aligned}
$$

Zgodnie $z$ oczekiwaniem, cribra orbitalia występują częściej (o ok. 9\%) u osobników z grobów bez wyposażenia, a szczególnie w grupie adultus (o ponad $17 \%$; $p<0,01$ ), niż u osobników z grobów z wyposażeniem. $\mathrm{Na}$ tej podstawie można wnioskować, że obecność wyposażenia w grobach jednak może wskazywać na lepsze warunki bytowe, jakie mieli za życia osobnicy z grupy W, przynajmniej w sensie stanu zdrowia i odżywiania. Natomiast w grupie maturus różnic nie ma (tab. 5). W tym kontekście ciekawie przedstawia się różnica między osobnikami mlodszymi i starszymi, pochodzącymi z grobów bez wyposażenia (o $14,5 \% ; p<0,05$ ). Prawdopodobnie skutki omawianego tu czynnika chorobowego (tj. anemii) warunkują wyższą umieralność osobników w mlodszym wieku, bytujących jednocześnie w gorszych warunkach. Wyższą śmiertelność w wyniku tego samego schorzenia wykryli m.in. także FORNACIARI i inni [1981]. Anemia bowiem między innymi obniża ogólną odporność organizmu, sprzyja zapadalności na choroby dróg oddechowych, choroby zakaźne itd. Zgodnie $z$ danymi wspomnianych poprzednio autorów, umieralnośc "nosicieli" cribra orbitalia w wieku mlodszym, zwlaszcza dziecięcym i mlodzieńczym jest znacznie wyższa, stąd obserwowane nierzadko malenie częstości występowania tej cechy w coraz starszych kategoriach wiekowych. Być może zatem można mówić o selektywnej umieralności osobników mających cribra orbitalia lub o selektywnej przeżywalności osobników nie mających tej cechy. Zdaniem niektórych badaczy (np. FORNACIARI i inni [1981]) przyczyny wywolujące pojawienie się cribra orbitalia są zarazem czynnikami podwyższonej śmiertelności. Zagadnienia te wymagają bardziej szczególowych badan.

\section{Cechy niemetryczsne a wyposażenie grobów}

Z tablicy 6 wynika, że między osobnikami $z$ grup BW i W nie ma różnic w częstościach występowania badanych cech niemetrycznych. Wyjątkiem są ossicula suturae lambdoideae, które jak wspomniano - naleźą do bardzo 
wrażliwych na czynniki środowiskowe elementów anatomicznych czaszki. Wyższy odsetek tych kostek (o ok. 13\%; $p<0,02$ ) ujawnil się W grupie BW. Podobną, choć mniej ostrą różnicę uzyskal RöSING [1982] na materiale staroegipskim.

Tabela 6. Cechy grupy I i II a wyposatenie grobów canzli żenskie (\% do $N$ stron)

\begin{tabular}{|c|c|c|c|}
\hline $\begin{array}{l}\text { Grups } \\
\text { coch }\end{array}$ & Cecha & BW & $\mathbf{w}$ \\
\hline I & $\begin{array}{l}\text { Sutura frontalis 1) } \\
\text { Tons palatinus 1) } \\
\text { Fonamen supraorbitale } \\
\text { Tubenculum praecondylane } \\
\text { Canalis hypoglossi } \\
\text { bipartitus }\end{array}$ & $\begin{array}{l}11,9 \\
(12 / 101) \\
57,5 \\
(50 / 87) \\
14,0 \\
(28 / 200) \\
9,0 \\
(14 / 156) \\
12,3 \\
(19 / 155)\end{array}$ & $\begin{array}{l}10,8 \\
(10 / 93) \\
59,2 \\
(45 / 76) \\
13,7 \\
(24 / 175) \\
7,3 \\
(9 / 124) \\
17,6 \\
(22 / 125)\end{array}$ \\
\hline II & $\begin{array}{l}\text { Foramen acusticum } \\
\text { Huschleei } \\
\text { Spina trachlearis } \\
\mathrm{M}_{3} \text { maxillae } \\
\text { Ossicula suctura } \\
\text { Lambdoideae }\end{array}$ & $\begin{array}{l}15,0 \\
(28 / 187) \\
12,1 \\
(23 / 190) \\
76,2 \\
(115 / 151 \\
\left.54,3^{2}\right) \\
101 / 186\end{array}$ & $\begin{array}{l}15,8 \\
(26 / 165) \\
10,6 \\
(17 / 161) \\
70,4 \\
(95 / 135) \\
41,52) \\
(71 / 171)\end{array}$ \\
\hline
\end{tabular}

Objafnienia:

BW = brak wyposażenia grobów, $\mathbf{W}=$ obecnosc wyposazenia grobow, 1) \% do $N$ osobników, 2) $p<0,02$

Wymienioną różnicę między obiema grupami, jak również poprzednio omówione różnice między nimi pod względem cribra orbitalia, można raczej lączyć jedynie $\mathrm{z}$ różnicą w poziomie warunków bytowych. Różnic $z$ innych powodów w ówczesnej populacji milickiej nie należy raczej spodziewać się, o ile bowiem wiadomo, na przyklad naplyw jakichs obcych grup nie mial tam wówczas miejsca.

Zdaniem wielu autorów procesy ksztaltowania się szwów i wyksztalcenia się kos- tek wstawnych w dużym stopniu zależą od wpływu czynników środowiskowych, które jako stresy sprzyjają odchyleniom od normalnego ich rozwoju [HEss 1946, BENNETT 1965, FINKEL 1971]. Wedlug FINKELA [1971] odchylenia takie występują częściej u kobiet. Z poprzednio omówionym czynnikiem chorobowym także związana byla zmiana częstości występowania kostek w szwie węglowym tylko u kobiet; uzyskany wynik pozostaje więc $w$ zgodzie $\mathrm{z}$ danymi wymienionych autorów. Zdaniem BENNETTA [1965] natomiast kostki dodatkowe w szwach w ogóle nie podlegają bezpośredniej kontroli genetycznej, lecz zależą od oddzialywań czynników zewnętrznych.

\section{Podsumowanie}

Wstępna analiza serii czaszek $(N=436)$ z cmentarzyska rzędowego w Miliczu, woj. wroclawskie (XII - XIV w.) umożliwila sformulowanie odpowiedzi na postawione we wstępie pytania.

Częstości występowania siedmiu spośród dziewięciu analizowanych cech niemetrycznych czaszki zależą od uwzględnionego czynnika chorobowego, tj. anemii wywolanej niedoborem żelaza (ewentualnie także robaczycą). Cechy te stanowią blisko $25 \%$ zespolu cech używanych zwykle do określania wielocechowych odleglości między populacjami. Wpływ wymienionego czynnika jest silniejszy u kobiet niż u mężczyzn.

W świetle analizy cribra orbitalia, osobnicy z grobów $\mathrm{z}$ wyposażeniem pochodzili z 
rodzin żyjących w nieco lepszych warunkach bytowych, przynajmniej $w$ sensie stanu zdrowia, odzywiania i higieny. Wyposażenie grobów mogloby zatem być wskaźnikiem poziomu warunków bytowych.

Skutki anemii warunkują prawdopodobnie wyższą umieralnosć osobników z mlodszej grupy wiekowej (adultus), żyjących jednocześnie w nieco gorszych warunkach bytowych.

Między osobnikami z grobów bez wyposażenia i z wyposażeniem nie ma różnic w częstościach występowania ośmiu spośród dziewięciu analizowanych cech; jedynie pod względem ossicula suturae lambdoideae różnice są statystycznie istotne. Czynnik chorobowy wywiera zatem wplyw na częstości występowania większej liczby cech, niż "średnio gorszy" poziom warunków bytowych.

Częstości występowania dwóch cech (foramen acusticum Huschkei $i$ spina trochlearis), spośród dziewięciu analizowanych, nie zależą ani od czynnika chorobowego, ani od poziomu warunków bytowych. Cechy niemetryczne zależne od czynników środowiskowych są raczej malo przydatne dla paleogenetyki populacyjnej.

Należy liczyć się z tym, że wielocechowe odleglości między populacjami mogą wskazywaé nie tylko na różnice etniczne lub genetyczne między nimi, lecz także na różnice uwarunkowane czynnikami środowiskowymi (różnice w poziomie warunków bytowych, stanie zdrowia, odżywiania, higieny itp.).

Sądzę, że uzyskane w tej pracy wyniki wskazują na konieczność dalszych badań w celu ustalenia optymalnego zespolu cech niemetrycznych dla potrzeb paleogenetyki populacyjnej.

\section{Piśmiennictwo}

ANGEL J., 1967, Porotic hyperostosis or osteoporosis symmetrica [w:] Diseases in Antiquity. A Survey of the Diseases, Injuries and Surgery of Early Popularions, (red.) D. Brothwell i A. T. Sandison, Ch. C. Thomas Publ., Springfield, Illinois, s. 378-389.

BENNETT K A., 1965, The etiology and genetics of Wormian bones. Amer. J. Phys. Anthrop., 23, 255-260.

BERGMAN P., G. HAUSER, 1985, Multi-dimensional complexes of skull traits, Anthropologischer Anzeiger, 43, $165-171$.

BERRY A. C., R. J. BERRY, 1967, Epigenetic variation in the human cranium, Journal of Anatomy, 101, 361-379.

BROTHWELL D. R., 1981, Digging up bones. The excavation, treatment and study of human skeletal remains, wyd. III, Oxford University Press, s. 165.

CARLSON D. S., D. P. van GERVEN, G. J. ARMELAGOS, 1974, Factors influencing the etiology of cribra orbitalia in prehistoric Nubia, Journal of Human Evolution, 3, 405-410.

Correnti V., P. Passarello, F. VECCHI, 1979, Discontinuous morphological traits of the human skeleton. A proposal for an intemational nomenclature in Latin, Homo, 30, 126-127

CORRUCCINI R. S., 1974, An examination of the meaning of cranial discrete traits for human skeletal biological studies, Amer. J. Phys. Anthrop., 40, 425-446.

CZARNETZKI A., 1971, Epigenetische Skelettmerkmale im Populationsvergleich. I. Rechts-links-Unterschiede bilateral angelegter Merkmale, Zschr. Morph. Anthrop., 63, 238-254.

CZARNETZKI A., 1972, Epigenetische Skelettmerkmale im Populationsvergleich. II. Frequenzunterschiede zwischen den Geschlechtern, Zschr. Morph. Anthrop. 63, 341-350.

FINKEL D. J., 1971, Wormian bones. A study of environmental stress (abstract), Amer. A. Phys. Anthrop., 35, 278.

Fornaciari G. J., F. MALlegNi, D. Bertini, V. NUTI, 1981, Cribra orbitalia, and elemental bone iron, in the Punics of Canhage, Ossa, 8, 63-77.

GLADYKOWSKA-RZECZYCKA J., 1982, Schorzenio swoiste ludnosci $z$ downych cmentarzysk Polski, Przegl. Antr., 48, 39-55.

GUIDOTTI A., 1984, Frequencies of cribra orbitalia in Central Italy (19th century) under special consideration of their degrees of expression, Anthrop. Anzeiger, 42. 11-16.

HAUSER G., P. BERGMAN, 1984, Some biological and methodological problems of asymmetrical development; illustrated with reference to sutural bones, Anthrop. Anzeiger, 42, 101-116. 
HENGEN O. P., 1971, Cribra orbitalia: pathogenesis and probable etiology, Homo, 22, 57-76.

Hess L., 1946, Ossicula Wormiana, Human Biology, 18, 61 80.

JANSSENS P. A., 1981, Porotic hyperostosis and goat's milk anaemia: a theory (more), Ossa, 8, 101-108.

NIKITJUK B. A., 1975, Objasnenie prixin akceleraci razvitija s učetom vzaimodejstvija nasledstvennych $i$ sredovych faktorov, Anthrop. Közlemények, 19, 169 177.

PERIZONIUS W.R. K, 1979, Non-metric cranial traits: sex difference and age dependence, J. Hum. Evol., 8, 679684.

REIMANN F., M. GOKMEN, 1966, Das Verhalien der Schädelnähre bei den jugendlichen schweren Eisenmangelanämien und sein Einfluss auf die Gestaltsveränderung des Schädels bei diesen Anämien, Archiv für KJinische Medizin, 212, 356-377.

REIMANN F., S. KURAN, 1973, Ursache, Entstehung und Wesen des "Bürstensyndroms" am Schädel bei schweren Erkrankungen des Blures, Virchowi Archiv, Abteilung A: Pathologische Anatomie, 358, 173-191.

ROSING F. W., 1982, Discresa des menschlichen Skelests ein kritischer Dberblick, Homo, 33, 100-125.

SANDFORD M.K, D.P. VAN GERVEN, R.R. MEGLEN, 1983, Elemental hair analysis: new evidence on the etiology of cribra orbitalia in Sudanese Nubia, Hum. Biol., 55, 831-844.

SANDISON A.T., 1967, Diseases of the eyes, [w:] Diseases in Aliquiry. A Survey of the Diseases, Injuries and Surgery of Early Populations, (red.) D. Brothwell i A. T.
Sandison, Ch. C. Thomas Publisber, Springfield, Illinois, s. 457-463.

STEINBOCK R. T., 1976, Paleopathological Diagnosis and Interpration. Bone Diseases in Ancient Human Populations. Ch. C. Thomas Publisher, Springfield, Illinois, 8. 239-252.

STLOUKAL M., 1970, Anthropologische Unterschiede bei Gräbem mis verschiedener Aussıatrung im Gräberfeld von Mikuleice, [w:] Sbornik Josefu Poulikovi k Jedesátinám. Ceskoslovenskă Akademia Vẻd, Archeologyckŷ Ứtav v Brně, \&. 121-127.

STLOUKAL M., L. VYHNÁNEK, 1976, Slované z velkomoravských Mikuľ̌ic, Acade mia, Praba, s. 147 150.

WACHOWSKI K, 1969, Wczesnotredniowieczne cmeniarzysko szkieletowe w Miliczu, cz. I. Silesia Antiqua, 11, 199-223.

WACHOWSKI K, 1970, Wczesnotredniowieczne cmentarysko szkieletowe w Miliczu, cz. II. Silesia Antiqua, 12, 123-187.

WACHOWSKI K, 1971, Wczesnosredniowieczne cmensarzysko szkieletowe $w$ Miliczu, cz. III. Silesia Antiqua, 13, 191-213.

WACHOWSKI K, 1975, Cmentarzyska doby wczesnopiastowskiej na Slqqsku, Ossolineum, Wroclaw.

WELCKER H., 1888, Cribra orbilalia, ein ethnologischdiagnostisches Merkmal am Schādel mehrer Menschenrassen, Archiv für Anthropologie, 17, 1-18.

Referat wygloszony na Konferencji Antropologicznej w Blazejewku, we wrześniu 1985 r.

\section{S u m m a r y}

The analysis of skulls $(N=436)$ from the aligned cemetery in Milicz. Lower Silesia (12th-14th CC. $)$ gave the following results. The frequencies of appearance of certain non-metric traits may undergo changes caused by a morbid factor (anaemia as a result of iron deficiency). The analysis of frequencies of appearance of cribra orbitalia shows that the presence of grave equipment versus lack of such equipment indicates a higher level of living conditions, at least in the sense of better health and nutritional status of the deceased individuals. Anaemia and its effects increased probably mortality especially in younger individuals (adulus group) who, at the same time, existed in worse living conditions. No differences were found in frequencies of appearance of the eight non-metric traits between individuals from equipped and non-equipped graves. However, the frequencies of appearance of ossicula suturae lambdoideae show statistically significant differences. It is emphasized that the multivariate distances between populations may point not only toward ethnic or genetic differences between them but also toward differences conditioned environmentally. 